\title{
Southeastern Brazilian tyrannulets as flower watchers
}

\author{
Edwin O'Neill Willis ${ }^{1,2}$ \& Glayson Ariel Bencke $e^{3,4}$
}

\author{
Instituto de Estudos da Natureza, Rio Claro, SP, Brazil. \\ In memoriam. \\ 3 Museu de Ciências Naturais, Fundação Zoobotânica do Rio Grande do Sul, Porto Alegre, RS, Brazil. \\ ${ }^{4}$ Corresponding author: gabencke@sema.rs.gov.br
}

Received on 01 March 2018. Accepted on 02 September 2019.

\begin{abstract}
Several species of insect-eating birds occasionally visit flowering trees or shrubs to feed on arthropods at flowers instead of nectar or petals. In southeastern Brazil, the Planalto Tyrannulet Phyllomyias fasciatus (10.3 g) and the Gray-headed TodyFlycatcher Todirostrum poliocephalum $(7 \mathrm{~g})$ often watch flowers to get insects and can visit flowering trees for hours or for several days. We describe the foraging behavior of these two tyrannulets at flowering trees and also report observations on several other species, mostly tyrant-flycatchers and tanagers. As an opportunistic foraging strategy, flower watching can be expected to be more common among small, canopy or edge birds that sally or hover-glean to catch small insects on or near foliage.
\end{abstract}

KEY-WORDS: foraging behavior, insects, Phyllomyias fasciatus, tanagers, Todirostrum poliocephalum, tyrant-flycatchers.

\section{INTRODUCTION}

Birds often visit flowers for nectar or to eat petals (Willis 2002). Insects attracted to flowers provide another type of food, and certain birds watch flowers to catch them. Pereyra (1941) noted many birds eating insects in flowering corn fields, and suggested that such birds as the Spectacled Tyrant Hymenops perspicillatus could help pollinate the crop. Beehler (1980) reported several species catching insects in flowering trees in New Guinea, and the Green Honeycreeper Chlorophanes spiza in Panama (as described earlier by Snow \& Snow 1971). Stiles et al. (1989) reported the Tropical Kingbird Tyrannus melancholicus getting butterflies near flowers, and stated that the Black-headed Tody-Flycatcher Todirostrum nigriceps often forages in flowering trees. Tampson (1990) noted the Cattle Tyrant Machetornis rixosa catching insects in palm flowers. Dobbs \& Greeney (2006) observed that nearly 1\% of insects captured by the Rufous-breasted Flycatcher Leptopogon rufipectus are taken on flowers.

Here, we discuss flower watching in southeastern Brazil by the Gray-headed Tody-Flycatcher Todirostrum poliocephalum, a close relative of T. nigriceps, and the Planalto Tyrannulet Phyllomyias fasciatus. These two tyrannulets occasionally visit flowers for hours, or for several days. We also report some observations for the Bran-colored Flycatcher Myiophobus fasciatus and others.

\section{METHODS}

Most observations were at the Santa Lúcia Biological Station (19 $58^{\prime}$ S; $40^{\circ} 32^{\prime} \mathrm{W}, 650 \mathrm{~m}$ a.s.l.) in the Santa Teresa mountain range of central Espírito Santo state, Brazil. Flowering trees were mainly cultivated avocados Persea americana (Lauraceae) and Japanese Plums Eriobotrya japonica (Rosaceae) by the laboratory and several native yellow-flowered Senna multijuga var. lindleyana (Fabaceae) along the entry road, $500 \mathrm{~m}$ upriver. Observations were made with $8 \times 30$ and $10 \times$ 42 binoculars from an appropriate distance so as not to disturb the birds.

G.A.B. studied insectivorous and omnivorous birds foraging at flowers of three neighboring avocados on 04 , 05 and 09 September 1994, for a total of $1405 \mathrm{~min}$. For each bird visitation, data recorded included species, number of individuals, arrival and departure time, foraging maneuvers and substrate of captures. Whenever it was not possible to record an individual's arrival or departure time, we used the average visit length calculated for the species. Foraging maneuvers were classified according to Remsen \& Robinson (1990) into eight categories. These categories were then combined with substrates of capture to generate composite codes representing foraging tactics (e.g., SH/F indicates a sally-hover to capture an insect on a flower). E.O.W. studied P. fasciatus, M. fasciatus and other species at flowers mainly April-May 1996. We also report observations on tyrant-flycatchers and other passerines 
made elsewhere in southeastern Brazil. Scientific names of birds follow Piacentini et al. (2015). Bird body masses are from Wilman et al. (2014).

\section{RESULTS}

In September 1994, twelve species foraged on insects attracted to avocado flowers at Santa Lúcia (Table 1). Ten others visited flowers exclusively for nectar (Thalurania glaucopis, Coereba flaveola and Dacnis cayana) or perched/foraged away from flowers (Cranioleuca pallida, Xenops rutilans, Piprites chloris, Camptostoma obsoletum, Lathrotriccus euleri, Euphonia violacea and Tangara cayana). Todirostrum poliocephalum, P. fasciatus and three tanagers visited the trees in more than one day and made considerably more visits or spent considerably more time foraging at flowers than other species (Table 1). Todirostrum poliocephalum spent the largest amount of time on trees and made long visits concentrated in the second half of the morning, when it was a regular and constant visitor. Typically, one bird of a pair that held a territory in the area would forage for long periods in the avocados, sometimes accompanied by its mate. Aerial maneuvers (short sally-strikes and, to a lesser extent, sallypounces and leaps) were used to capture prey mainly on substrates other than air, and about $65 \%$ of captures were on or very close to flowers (Table 2).

Phyllomyias fasciatus was the most frequent species in the avocados. It made medium-length regular visits throughout the morning and early afternoon (Table 1). Usually only one or two birds foraged in the trees at the same time, but up to four were present on some occasions. Prey were mostly captured in the air or at flowers with sally-strikes and, less frequently, sally-hover and sally-pounce maneuvers. Nearly $62 \%$ of insectcatching attempts were at or near flowers (Table 2). This species showed the greatest range of foraging maneuvers among all visitors.

The avocado flowers were visited earlier by a $T$. poliocephalum on 03 September 1994, with short strikes under leaves near the flowers. We have often seen it sallying under leaves away from flowers, at dense vine tangles in woods or at edges. E.O.W. also noted visits by two $P$. fasciatus, which sallied to the air or leaves near flowers at 10-12 h. Later, two birds were sallying in a small flowering tree (not identified) in the woods downriver. We have seen it sallying away from flowers, or getting Myrsine fruit or Alchornea arils, on other occasions.

On 24 April 1996, 16:22-16:28 h, one P. fasciatus sallied for insects in the Senna. On the 25 April, between 9-10 h, two were now and then near Japanese Plum flowers by the lab, between visits by tanagers and relatives that poked their bills deep into the flowers (D. cayana, Tangara seledon and Schistochlamys ruficapillus). A T. poliocephalum worked briefly near one of the P. fasciatus, but soon left. On the 26 April, E.O.W. watched at the Senna from 15:24 h to dark at 17:30 h. The main visitor was a $M$. fasciatus, but two $P$. fasciatus worked $16: 00 \mathrm{~h}$ in the crowns, sallying to catch insects on flowers several times.

Table 1. Number of visits on each day of observation, total number of visits, mean length of visits (min), total time spent on trees (min) and average number of individuals per visit for birds recorded foraging on insects attracted to avocado flowers at Santa Lúcia, Espírito Santo state, Brazil, in September 1994.

\begin{tabular}{lcccccccc}
\hline \multirow{2}{*}{ Species } & \multicolumn{2}{c}{ No. of visits/day } & Total No. & Mean length \\
\cline { 2 - 5 } & $\begin{array}{c}\mathbf{0 4} \\
\text { of visits }\end{array}$ & $\begin{array}{c}\mathbf{0 5} \\
\text { Sept }\end{array}$ & $\begin{array}{c}\mathbf{0 9} \\
\text { Sept }\end{array}$ & $\begin{array}{c}\text { Total time } \\
\text { opent on } \\
\text { trees }\end{array}$ & $\begin{array}{c}\text { Average No. } \\
\text { of individuals } \\
\text { per visit }\end{array}$ \\
\hline Todirostrum poliocephalum & - & 3 & 8 & 11 & 26.3 & 289 & 1.1 \\
Phyllomyias fasciatus & - & 8 & 19 & 27 & 9.2 & 249 & 1.2 \\
Saltator maximus & - & 1 & 7 & 8 & 8.9 & 71 & 1.0 \\
Tangara ornata & - & 3 & 17 & 20 & 2.8 & 56 & 1.3 \\
Tangara sayaca & - & 1 & 4 & 5 & 5.0 & 25 & 1.6 \\
Tolmomyias sulphurescens & - & - & 6 & 6 & $3.2^{*}$ & $19.5 *$ & +1.0 \\
Hemitriccus nidipendulus & 2 & - & 1 & 3 & 3.0 & 9 & 1.0 \\
Pachyramphus castaneus & - & 1 & 2 & 3 & 1.7 & 5 & 1.0 \\
Pachyramphus viridis & - & - & 2 & 2 & 1.2 & 2.5 & 1.0 \\
Contopus cinereus & - & - & 2 & 2 & 0.7 & 1.5 & 1.0 \\
Piaya cayana & - & - & 1 & 1 & 1.0 & 1 & 1.0 \\
Hylophilus poicilotis & - & 1 & - & 1 & 1.0 & 1 & 1.0 \\
\hline Total & $\mathbf{2}$ & $\mathbf{1 8}$ & $\mathbf{6 9}$ & $\mathbf{8 9}$ & - & - & - \\
\hline
\end{tabular}

*possibly overestimated because the length of some visits could not be determined. 
Table 2. Frequency of use of foraging tactics by five species with the longest time of association with flowering avocados at Santa Lúcia, Espírito Santo state, Brazil, in September 1994. Attack maneuvers: SS - sally-strike; SP - sally-pounce; SH - sally-hover; FCh - flutter-chase; Le - leap; Lu - lunge; RO - reach-out; RU - reach-up (from Remsen \& Robinson 1990). Substrates: A - air; F - flower; UL - upper surface of leaves; LL - lower surface of leaves; B - branch; Fo - foliage (used when a substrate other than air could not be determined). An asterisk after the substrate code indicates captures near flowers.

\begin{tabular}{|c|c|c|c|c|c|}
\hline $\begin{array}{l}\text { Maneuver/ } \\
\text { substrate }\end{array}$ & $\begin{array}{l}\text { Phyllomyias } \\
\text { fasciatus }\end{array}$ & $\begin{array}{c}\text { Todirostrum } \\
\text { poliocephalum }\end{array}$ & $\begin{array}{c}\text { Tangara } \\
\text { ornata }\end{array}$ & $\begin{array}{c}\text { Tangara } \\
\text { sayaca }\end{array}$ & $\begin{array}{l}\text { Saltator } \\
\text { maximus }\end{array}$ \\
\hline SS/A (SS/A*) & $49(26)$ & $7(5)$ & - & $3(2)$ & 2 \\
\hline SS/F & 26 & 18 & 2 & - & 2 \\
\hline $\mathrm{SS} / \mathrm{LL}$ & 2 & 3 & - & - & - \\
\hline SS/UL & 3 & - & - & - & - \\
\hline SS/Fo & 5 & - & - & - & 1 \\
\hline SS/B & 2 & 4 & - & - & - \\
\hline SP & - & - & 1 & - & 1 \\
\hline $\mathrm{SP} / \mathrm{F}$ & 6 & 5 & - & - & - \\
\hline $\mathrm{SP} / \mathrm{Fo}$ & 1 & - & - & - & - \\
\hline $\mathrm{SH}$ & 1 & - & - & - & - \\
\hline $\mathrm{SH} / \mathrm{F}$ & 6 & - & - & - & - \\
\hline $\mathrm{FCh}$ & - & - & 1 & 1 & - \\
\hline Le & - & - & 3 & - & - \\
\hline Le/A & 2 & - & - & - & - \\
\hline Le/B (Le/B*) & $1(1)$ & 2 & - & - & - \\
\hline $\mathrm{Le} / \mathrm{F}$ & 2 & 2 & - & 1 & - \\
\hline $\mathrm{Le} / \mathrm{LL}$ & - & 2 & - & - & - \\
\hline $\mathrm{Le} / \mathrm{Fo}$ & - & 2 & - & - & - \\
\hline $\mathrm{Lu}$ & 2 & - & 1 & 1 & - \\
\hline $\mathrm{Lu} / \mathrm{F}$ & - & - & - & 1 & - \\
\hline $\mathrm{RO}$ & - & 1 & - & - & - \\
\hline $\mathrm{RO} / \mathrm{F}$ & 1 & 1 & - & - & - \\
\hline $\mathrm{RO} / \mathrm{A}^{*}$ & 1 & - & 1 & - & - \\
\hline $\mathrm{RO} / \mathrm{UP}$ & - & 1 & - & - & - \\
\hline $\mathrm{RU} / \mathrm{F}$ & 1 & - & - & - & - \\
\hline RU/A* & - & - & 1 & - & - \\
\hline$n$ & 111 & 48 & 10 & 7 & 6 \\
\hline
\end{tabular}

On 14 May, 15:54 h, two P. fasciatus were back to the Senna and worked near flowers, at times pecking deep inside, 16:00-16:10 h. After $5 \mathrm{~min}$ in the low bushes below, one returned for 3 min to sally to air or leaves near flowers, and again at 16:21 h for several sallies to the air, then dropping to a Cecropia below. A third bird and the two moved into the Senna 16:24 h to $16: 32 \mathrm{~h}$, then wandered off. At 16:42 h, a $P$. fasciatus returned for six more short sallies to the air, moving off by 16:50 h.

On 19 May, there were several visits by $P$. fasciatus. Between 14:38-14:51 h one did ten air sallies and three pecks into flowers before preening, then five other sallies (all next to flowers or leaves). At 15:44 h, two were in the Senna trees, sallying four times before moving to a Myrsine bush with tiny flowers. Between 16:01-16:04 h, two $P$. fasciatus returned, sallying eight times or more to the air by flowers. Between 16:10-16:34 h one worked the flowers, preening and regurgitating two seeds on a twig and defecating another, before 32 short sallies to near flowers 16:19-16:32 h. Between 16:36-16:38 h, one returned for five short sallies, then to a Cecropia off east. Two and then three birds continued to sally in the area 16:40 $\mathrm{h}$ on, using other trees and a telephone wire, but between 17:00-17:10 h some sallies were again near 
flowers, after which birds wandered off for the night.

On most days, the $M$. fasciatus worked low bushes under or near the Senna. On 26 April, however, one sallied in the midlevels of the Senna at 15:46 h, returning 15:52 $\mathrm{h}$ after some long calls and sallying to near flowers. It fled if people or bicycles passed, but returned to catch insects with sallies to flowers, the air, or foliage; at 16:23 $\mathrm{h}$ it dropped to bushes, sallied to the ground in the road a few times, and did not return to the flowers. The next morning, 08:05-08:15 h, the $M$. fasciatus was less timid and sallied to or near flowers up one tree several times.

Elsewhere, E.O.W. noted $P$. fasciatus, M. fasciatus and six other small flycatchers sallying or hovering for insects near flowers of trees or bushes in southeastern Brazil (Table 3). Late on 15 August 2002, fallen flowers of Tabebuia chrysotricha (Bignoniaceae) on the lawn of the UNESP Campus $\left(22^{\circ} 23^{\prime} \mathrm{S}\right.$; $47^{\circ} 33^{\prime} \mathrm{W}, 620 \mathrm{~m}$ a.s.l.), Rio Claro, São Paulo state, attracted insect-eating birds such as the Great Kiskadee Pitangus sulphuratus, M. rixosa, woodpeckers, wrens and others, while flowers in the trees nearby attracted the Yellow-bellied Elaenia Elaenia flavogaster and the White-crested Tyrannulet Serpophaga subcristata.

In southern Brazil, G.A.B. noticed two other tyrant-flycatchers watching flowers of bushes to catch insects (Table 3). In addition, in the Pampas grasslands around Lavras do Sul $\left(30^{\circ} 48^{\prime} \mathrm{S}\right.$; 53ㄷ' $4^{\prime} \mathrm{W}, 315 \mathrm{~m}$ a.s.l.), 05-08 January 2018, at least three species of tyrantflycatchers were plucking soldier beetles Chauliognathus flavipes (Cantharidae) from the umbellate flower stalks of Eryngium chamissonis (Urb., 1879) (Apiaceae) in densely vegetated upland swales dominated by this spiny sedge. These polymorphic, soft-elytra beetles are distinctly colored with yellow and black and gather by the thousands on the upright inflorescences of E. chamissonis, which rise up to $1.5 \mathrm{~m}$ above the vegetative stratum in midsummer to form a temporary emergent layer of flowering shoots. Birds seen capturing the beetles in a more or less systematic way included a family group of Yellow-browed Tyrants Satrapa icterophrys on the 04 January, plus a solitary individual on the 06 January, and two M. fasciatus on the 05 and 08 January, at four different locations. One

Table 3. Observations of tyrant-flycatchers (Rhynchocyclidae and Tyrannidae) foraging on insects attracted by flowers in southeastern Brazil.

\begin{tabular}{|c|c|c|c|}
\hline Species & Plant (family) & $\begin{array}{l}\text { Locality (coordinates, altitude, } \\
\text { a.s.l.)* }\end{array}$ & Date (observer) ${ }^{* *}$ \\
\hline $\begin{array}{l}\text { Phylloscartes ventralis } \\
\text { Mottle-cheeked } \\
\text { Tyrannulet }\end{array}$ & $\begin{array}{l}\text { Rubus rosifolius } \\
\text { (Rosaceae) }\end{array}$ & $\begin{array}{l}\text { Mariana Pimentel, RS } \\
\left(30^{\circ} 19^{\prime} \mathrm{S} ; 51^{\circ} 36^{\prime} \mathrm{W}, 230 \mathrm{~m}\right)\end{array}$ & 18 July 1997 (1) \\
\hline $\begin{array}{l}\text { Tolmomyias sulphurescens } \\
\text { Yellow-olive Flycatcher }\end{array}$ & $\begin{array}{l}\text { Ceiba speciosa } \\
\text { (Malvaceae) }\end{array}$ & $\begin{array}{l}\text { near Broa Reservoir, SP } \\
\left(22^{\circ} 08^{\prime} \mathrm{S} ; 47^{\circ} 52^{\prime} \mathrm{W}, 740 \mathrm{~m}\right)\end{array}$ & 25 March 1984 (2) \\
\hline $\begin{array}{l}\text { Todirostrum cinereum } \\
\text { Common Tody- } \\
\text { Flycatcher }\end{array}$ & Inga sp. (Fabaceae) & $\begin{array}{l}\text { Sooretama, ES } \\
\left(19^{\circ} 03^{\prime} \mathrm{S} ; 40^{\circ} 09^{\prime} \mathrm{W}, 85 \mathrm{~m}\right)\end{array}$ & 27 December 1992 (2) \\
\hline \multirow{2}{*}{$\begin{array}{l}\text { Phyllomyias fasciatus } \\
\text { Planalto Tyrannulet }\end{array}$} & $\begin{array}{l}\text { Vochysia sp. } \\
\text { (Vochysiaceae) }\end{array}$ & $\begin{array}{l}\text { Rio do Cipó, MG } \\
\left(18^{\circ} 40^{\prime} ; 43^{\circ} 59^{\prime}, 570 \mathrm{~m}\right)\end{array}$ & 20 December 1997 (2) \\
\hline & unidentified bush & $\begin{array}{l}\text { Campos do Jordão, SP } \\
\left(22^{\circ} 38^{\prime} \mathrm{S} ; 45^{\circ} 26^{\prime} \mathrm{W}, 1600 \mathrm{~m}\right)\end{array}$ & 11 August 2001 (2) \\
\hline $\begin{array}{l}\text { Phyllomyias griseocapilla } \\
\text { Gray-capped Tyrannulet }\end{array}$ & unidentified flowers & $\begin{array}{l}\text { Augusto Ruschi Biological Reserve, ES } \\
\left(19^{\circ} 54^{\prime} \mathrm{S} ; 40^{\circ} 33^{\prime} \mathrm{W}, 850 \mathrm{~m}\right)\end{array}$ & September 2002 (2) \\
\hline $\begin{array}{l}\text { Culicivora caudacuta } \\
\text { Sharp-tailed Tyrant }\end{array}$ & tiny flowers of bushes & $\begin{array}{l}\text { Broa prairie, SP } \\
\left(22^{\circ} 14^{\prime} \mathrm{S} ; 47^{\circ} 52^{\prime} \mathrm{W}, 715 \mathrm{~m}\right)\end{array}$ & 14 June 2002 (2) \\
\hline $\begin{array}{l}\text { Myiarchus swainsoni } \\
\text { Swainson's Flycatcher }\end{array}$ & $\begin{array}{l}\text { unidentified yellow } \\
\text { flowers }\end{array}$ & $\begin{array}{l}\text { Intervales, SP } \\
\left(24^{\circ} 16^{\prime} \mathrm{S} ; 48^{\circ} 25^{\prime} \mathrm{W}, 830 \mathrm{~m}\right)\end{array}$ & 04 March 1988 (2) \\
\hline $\begin{array}{l}\text { Myiarchus ferox } \\
\text { Short-crested Flycatcher }\end{array}$ & $\begin{array}{l}\text { Croton floribundus } \\
\text { (Euphorbiaceae) }\end{array}$ & $\begin{array}{l}\text { Fazenda São José, SP } \\
\left(22^{\circ} 21^{\prime} S ; 47^{\circ} 29^{\prime} \mathrm{W}, 650 \mathrm{~m}\right)\end{array}$ & 12 January 1992 (2) \\
\hline $\begin{array}{l}\text { Myiophobus fasciatus } \\
\text { Bran-colored Flycatcher }\end{array}$ & Inga sp. (Fabaceae) & Fazenda São José, SP & 09 September 2001 (2) \\
\hline $\begin{array}{l}\text { Muscipipra vetula Shear- } \\
\text { tailed Gray Tyrant }\end{array}$ & $\begin{array}{l}\text { Tecoma stans } \\
\text { (Bignoniaceae) }\end{array}$ & $\begin{array}{l}\text { Monte Alverne, RS } \\
\left(29^{\circ} 34^{\prime} \mathrm{S} ; 52^{\circ} 22^{\prime} \mathrm{W}, 350 \mathrm{~m}\right)\end{array}$ & 23 September 1995 (1) \\
\hline
\end{tabular}


Highland Elaenia Elaenia obscura also briefly fed on the insects on the first day. Beetles were picked or snapped off flower heads and outermost peduncles mostly with glean, reach and leap maneuvers, and the birds seemed to make little effort to catch them, since prey was everywhere and almost stationary.

\section{Other species}

On 27 April 1996, a tanager flock visited Senna trees by the lab of the Museu de Biologia Mello Leitão (19 ${ }^{\circ} 58^{\prime} \mathrm{S}$; $40^{\circ} 36^{\prime} \mathrm{W}, 680 \mathrm{~m}$ a.s.l.), Santa Teresa, sallying to air or leaves for insects near or far from flowers (Tangara palmarum, T. ornata, T. sayaca, and T. cayana). A female Barred Antshrike Thamnophilus doliatus pecked an insect from a Bauhinia flower (Fabaceae) at Barão Geraldo District $\left(22^{\circ} 50^{\prime}\right.$ S; $47^{\circ} 05^{\prime} \mathrm{W}, 620 \mathrm{~m}$ a.s.l.), Campinas, São Paulo state, on 06 June 1998 (E.O.W.). On 15 October 1995, a male Hepatic Tanager Piranga flava worked the crown of a flowering Phytolacca dioica tree (Phytolaccaceae) for about $25 \mathrm{~min}$ at Itati $\left(29^{\circ} 23^{\prime} \mathrm{S}\right.$; $50^{\circ} 11^{\prime} \mathrm{W}, 230 \mathrm{~m}$ a.s.l.), Rio Grande do Sul state, hopping and jumping along branches to catch insects on or near flowers with short sallies, flutter-chases and one reach-out; the bird often watched closely the movements of flying insects around flowers before attempting to capture its prey (G.A.B.).

\section{DISCUSSION}

The temporary association of insect-eating birds with flowering trees or shrubs is scarcely documented in the literature. We expect this opportunistic behavior to be more common among small-bodied, edge or canopydwelling birds that sally or hover-glean to catch small insects on or near foliage, because $i$ ) insects attracted to flowers are usually small (mostly hymenopterans, flies and beetles, but also butterflies and moths; Willmer 2011), making them non-rewarding prey for larger birds; ii) plant species showing massive flowering (i.e., producing large numbers of exposed flowers to attract relatively nonspecialized pollinators) predominate in the upper strata of tropical forests and along borders (Janzen 1975, Baker et al. 1983); and iii) flowers are rarely accessible directly to perching birds in the New World (Cronk \& Ojeda 2008).

In southeastern Brazil, P. fasciatus $(10.3 \mathrm{~g})$ often watches flowers and sallies for or pecks insects, $T$. poliocephalum (7 g) and M. fasciatus (9.9 g) less. As illustrated here, many other birds (mass range 6.3-102 g) visit flowering trees to get insects, but they move through the trees and do not obviously watch flowers as do the tyrannulets above, or perhaps do it for shorter periods (e.g., Piranga flava). Wholly insectivorous birds such as T. poliocephalum may forage in flowering trees for longer periods as compared to similarly sized species that also feed on fruits, presumably because they are able to find most of their food items in the flowers and/or foliage, and also because arthropods at flowers are a rapidly renewing resource (Beehler 1980). In contrast, P. fasciatus and several tanagers make more frequent but shorter visits to flowering trees, possibly because insects are only part of their diet. Individuals of $P$. fasciatus observed at Santa Lúcia often regurgitated mistletoe seeds upon arriving at the flowering trees, indicating they had been feeding on fruit shortly before.

Several other Tyrannoidea visit eucalyptus or other flowers, but more study is needed to establish whether arthropods, nectar, or pollen are used. We did not confirm any activity that could have pollinated flowers, except when one bird put its head in a flower. Flight near flowers could have picked up some pollen, but tanagers and others that visit flowers directly are more likely to pollinate.

\section{ACKNOWLEDGEMENTS}

We wish to express our gratitude to Yoshika Oniki-Willis for her generous assistance and to two anonymous referees for valuable comments on the manuscript. We appreciate the logistic support and permission provided by the managers of the various protected areas we visited. G.A.B. benefited from scholarship support by the Coordenação de Aperfeiçoamento de Pessoal de Nivel Superior (CAPES). Publication number 79 of the Institute for Studies of Nature.

\section{REFERENCES}

Baker H.G., Bawa K.S., Frankie G.W. \& Opler P.A. 1983. Reproductive biology of plants in tropical forests, p. 183-215. In: Golley F.B. (ed.). Tropical rainforest ecosystems: ecosystems of the world. New York: Elsevier.

Beehler B. 1980. A comparison of avian foraging at flowering trees in Panama and New Guinea. Wilson Bulletin 92: 513-519.

Cronk Q. \& Ojeda I. 2008. Bird-pollinated flowers in an evolutionary and molecular context. Journal of Experimental Botany 59: 715727.

Dobbs R.C. \& Greeney H.F. 2006. Nesting and foraging ecology of the Rufous-breasted Flycatcher (Leptopogon rufipectus). Ornitologia Neotropical 17: 173-181.

Janzen D.H. 1975. Ecology of plants in the tropics. London: Edward Arnold.

Pereyra J.A. 1941. Polinización de las flores por las aves. Hornero 8: 222-224.

Piacentini V.Q., Aleixo A., Agne C.E., Maurício G.N., Pacheco J.F., Bravo G.A., Brito R.R.R., Naka L.N., Olmos F., Posso S., Silveira L.F., Betini G.S., Carrano E., Franz I., Lees A.C., Lima L.M., Pioli D., Schunck F., Amaral F.R., Bencke G.A., Cohn-Haft M., Figueiredo L.F.A., Straube F.C. \& Cesari E. 2015. Annotated checklist of the birds of Brazil by the Brazilian Ornithological Records Committee. Revista Brasileira de Ornitologia 23: 91-298. 
Remsen J.V. \& Robinson S.K. 1990. A classification scheme for foraging behavior of birds in terrestrial habitats, p. 144-160. In: Morrison M.L., Ralph C.J., Verner J. \& Jehl-Jr. J.R. (eds.). Avian foraging: theory, methodology, and applications. San Diego: Cooper Ornithological Society (Studies in Avian Biology No. 13).

Snow B.K. \& Snow D.W. 1971. The feeding ecology of tanagers and honeycreepers in Trinidad. Auk 88: 291-322.

Stiles F.G., Skutch A.F. \& Gardner D. 1989. A guide to the birds of Costa Rica. Ithaca: Cornell University Press.

Tampson V.E. 1990. Lista comentada das espécies de aves registradas para o Morro do Espelho, Sáo Leopoldo, Rio Grande do Sul,
Brasil (1983-1988). Acta Biologica Leopoldensia 12: 19-37.

Willis E.O. 2002. Birds at Eucalyptus and other flowers in southern Brazil: a review. Ararajuba 10: 43-66.

Wilman H., Belmaker J., Simpson J., Rosa C., Rivadeneira M.M. \& Jetz W. 2014. EltonTraits 1.0: species-level foraging attributes of the world's birds and mammals. Ecology 95: 2027.

Willmer P. 2011. Pollination and floral ecology. Oxford: Princeton University Press.

Associate Editor: Caio G. Machado. 